\title{
Komunikasi Antarpribadi Orang Tua Dan Anak Dalam Memilih Calon Pasangan Hidup
}

\author{
Nurul Saniah, S.Sos. I MA \\ Universitas Potensi Utama \\ nurulsaniah@ymail.com
}

\begin{abstract}
ABSTRAK
Manusia tidak akan bisa berkembang dan maju tanpa adanya komunikasi dengan manusia lainnya. Karena manusia membutuhkan orang lain dalam kehidupannya dan tidak bisa hidup sendiri dan menyendiri di dunia ini. Komunikasi sudah ada semenjak terciptanya manusia pertama yaitu Nabi Adam AS dan memang sudah fitrahnya manusia harus berkomunikasi dengan orang lain. Karena tanpa adanya komunikasi maka dunia ini akan mengalami perubahan. Salah satu komunikasi yang ada adalah komunikasi antarpribadi, yaitu komunikasi yang dilakukan seorang individu dangan individu lainnya. Bentuk khusus dari komunikasi antarpribadi ini adalah komunikasi yang melibatkan hanya dua orang secara tatap-muka, yang memungkinkan setiap pesertanya menangkap reaksi orang lain secara langsung, baik secara verbal ataupun nonverbal, seperti suamiisteri, anak dan oang tuanya, dua sejawat, dua sahabat dekat, seorang guru dengan seorang muridnya, dan sebagainya.

Penelitian ini bertujuan untuk mengetahui apa saja yang dilakukan orang tua dalam berkomunikasi dengan anaknya dalam memilih calon pasangan hidup. Setelah melakukan komunikasi antarpribadi dengan anak bagaimana respon sang anak terhadap komunikasi yang diberikan orang tuanya. Komunikasi yang terjalin antara anak dan orang tua berguna untuk anak agar tidak salah dalam memilih pasangan hidup yang tidak hanya disukainya sendiri tetapi juga disukai dan direstui orang tuanya.
\end{abstract}

Kata kunci : Komunikasi antarpribadi, orang tua dan anak, calon pasangan hidup

\section{PENDAHULUAN}

Dalam kehidupan sehari-hari tidak terlepas dari komunikasi, karena tanpa adanya komunikasi manusia tidak akan bisa mendapatkan apa yang diinginkannya. Komunikasi pada dasarnya sangat penting dalam kehidupan manusia, karena dengan adanya komunikasi banyak hal yang dapat dilakukan manusia. Seperti orang yang sedih bisa jadi senang, dan orang yang pada awalnya sendiri bisa banyak teman, bahkan dengan adanya komunikasi bisa menyatukan laki-laki dan perempuan menjadi ikatan pernikahan. Semuanya itu membutuhkan komunikasi yang baik antara orang yang bersangkutan. Sebagaimana yang telah di jelaskan oleh Hafied Cangara dalam bukunya pengantar ilmu komunikasi sebagai berikut: sebagai makhluk sosial manusia senantiasa ingin berhubungan dengan manusia lainnya. Ia ingin mengetahui lingkungan sekitarnya, bahkan ingin 
mengetahui apa yang terjadi dalam dirinya. Rasa ingin tahu ini memaksa manusia perlu berkomunikasi. (Cangara:2005)

Dalam komunikasi antar orang tua dan anaknya yaitu komunikasi yang dilakukan hampir setiap harinya. Karena pada umumnya jalinan antara orang tua dan anak tidak bisa lepas dari komunikasi. Anak- anak membutuhkan figur dalam masa pertumbuhan mereka. Maka dari itu, orangtua haruslah bertindak sebagai cermin bagi anak-anak. Dan komunikasi yang baik akan menjadi perantara serta menjembatani kepentingan dan kemauan diantara keduanya. Setiap orang tua pasti menginginkan yang terbaik untuk anaknya. Tidak ada orang tua yang ingin menyesatkan anaknya. Begitu juga dalam urusan memilih calon pasangan hidup. Para orang tua pasti menginginkan anaknya mendapat calon pasangan hidup yang ideal. Banyak syarat-syarat yang diinginkan para orang tua untuk pasangan hidup anaknya kelak. Begitu juga sang anak pasti mempunyai criteria untuk calon pasangan hidupnya kelak. Dalam membangun komunikasi yang baik antara orang tua dan anak harus ditanamkan sejak dini. Agar anak terbiasa menceritakan semua yang berkenaan dengan dirinya. Termasuk dalam memilih calon pasangan hidupnya. Para orang tua hendaknya selalu memperhatikan semua yang terjadi pada diri anaknya Melihat kenyataannya bahwa masih banyak para orang tua yang memberikan kebebasan kepada anaknya untuk mencari calon pasangan hidupnya tanpa langsung berkomunikasi. Padahal sebaiknya sebelum memilih pasangan hidup seorang anak harus berkomunikasi dengan orang tua nya. Agar sama-sama sepakat antara keputusan anak dan orang tua nya sehingga tidak menimbulkan kecekcokan di antara keduanya.

Sang anak juga terkadang tidak mau membicarakan tentang calon pasangan hidup kepada orang tuanya. Karena sudah merasa pilihannya adalah orang yang tepat untuk dirinya. Padahal dalam membina rumah tangga itu bukanlah hal yang sangat mudah, banyak rintangan dan halangan di dalamnya, memang begitulah kehidupan berumah tangga penuh dengan lika-liku, baik suka maupun duka, yang semuanya harus dijalani kedua belah pihak baik suami maupun istri. Oleh sebab itu sebelum menentukan calon pasangan hidup harus dalam pertimbangan yang matangmatang. Karena kehidupan berumah tangga bukan untuk sehari, seminggu, sebulan, atau setahun saja, melainkan untuk seumur hidup. Begitu juga yang terjadi dalam keluarga yang menjadi subjek penelitian ini, para orang tua memberikan kebebasan pada anaknya dalam memilih calon pasangan hidupnya tanpa adanya campur tangan orang tuanya. Padahal dalam memilih calon pasangan hidup 
itu harus dengan pertimbangan yang matang-matang, agar tidak menyesal di kemudian hari. Ini menjadi suatu kajian yang sangat menarik, bagaimana jika orang tua dan anak sama-sama menyukai calon pasangan hidup anaknya kelak. Tidak hanya disukai anaknya tapi orang tua nya juga menyetujui pilihan anaknya

\section{METODE PENELITIAN}

\subsection{Jenis penelitian}

Adapun jenis penelitian ini adalah penelitian kualitatif yang menititikberatkan pada penelitian studi kasus. Studi kasus merupakan tipe pendekatan dalam penelitian yang penelaahannya kepada satu kasus dilakukan secara intensif, mendalam mendetail, dan komprehensif. (Faisal:2018) Studi kasus yang dilakukan adalah pada suatu keluarga yang mempunyai anak yang ingin mengenalkan calon pasangan hidupnya kepada keluarga dan orang tuanya. Dalam penelitian kualitatif dikenal ada dua strategi analisis data yang sering digunakan bersama-sama atau secara terpisah yaitu model strategi analisis deskriptif kualitatif dan atau model strategi analisis verifikatif. Kedua model analisis itu memberi gambaran bagaimana alur logika analisis data pada penelitian kualitatif sekaligus memberi masukan terhadap bagaimana teknik analisis data kualitatif digunakan.

\subsection{Sumber Data}

Data yang diperoleh berupa data primer dan data sekunder, data primer adalah data yang langsung diperoleh dari sumber data pertama di lokasi penelitian atau objek penelitian. Sedangkan data sekunder adalah data yang diperoleh dari sumber kedua atau sumber sekunder dari data yang kita butuhkan. Data primer dalam penelitian ini adalah data yang langsung diperoleh dari informan penelitian yaitu keluarga yang mempunyai anak yang sudah mempunyai calon pasangan hidup.

\subsection{Analisis Data}

Analisis data dilakukan oleh peneliti untuk dapat menarik kesimpulan-kesimpulan. Dalam penelitan komunikasi kualitatif, sebagaimana dalam penelitian kualitatif di dalam cabang ilmu yang lain, dikenal banyak jenis teknik analisis data yang semuanya sangat tergantung pada tujuan penelitian. Kendati demikian, analisis data dalam penelitian komunikasi kualitatif pada dasarnya 
dikembangkan dengan maksud hendak memberikan makna terhadap data, menafsirkan atau menstransformasikan data ke dalam bentuk -bentuk narasi yang kemudian mengarah pada temuan yang bernuansakan prosisi-prosisi ilmiah yang akhirnya pada kesimpulan-kesimpulan yang final. (pawito: 2007).

\section{HASIL PENELITIAN DAN PEMBAHASAN}

\subsection{Membina Komunikasi Antar Orang Tua dan Anak}

Kegiatan komunikasi interpersonal merupakan kegiatan sehari-hari yang paling banyak dilakukan oleh makhluk manusia sebagai makhluk sosial. Sejak bangun tidur di pagi hari sampai tidur lagi di larut malam, sebagian besar dari waktu kita digunakan untuk berkomunikasi dengan manusia lain. Dengan demikian kemampuan berkomunikasi merupakan suatu kemampuan yang paling dasar. Akan tetapi dalam kehidupan sehari-hari sering mengalami perbedaan pendapat, ketidaknyamanan situasi atau bahkan terjadi konflik yang terbuka disebabkan adanya kesalahpahaman dalam berkomunikasi. Menghadapi situasi seperti ini. Manusia baru akan menyadari bahwa diperlukan pengetahuan mengenai bagaimana cara berkomunikasi yang baik dan efektif yang harus dimiliki seorang manusia.(Kholil: 2011)

Begitu juga dengan komunikasi antar pribadi oang tua dan anak yang dilakukan hampir setiap harinya. Karena diantara kedua nya terjadi ikatan bathin yang sangat kuat. Selain itu juga orang tua dan anak sering tinggal bersama dalam satu rumah. Jarang ada anak yang terpisah dari orang tuanya. Kecuali ada keperluan-keperluan lain seperti sekolah, kuliah, bekerja dan menikah. Walaupun demikian komunikasi antar orang tua dan anak tetap terjalin juga melalui handphone, surat, dan lain-lain.

Komunikasi antarpribadi pada dasarnya merupakan jalinan hubungan interaktif antara seorang individu dan individu lain dimana lambang-lambang pesan secara efektif digunakan, terutama lambang-lambang bahasa. Penggunaan lambang-lambang bahasa verbal, terutama yang bersifat lisan, di dalam kenyataan kerapkali disertai dengan bahasa isyarat terutama gerak atau bahasa tubuh (body language), seperti senyuman, tertawa dan menggeleng atau mengangukkan kepala. Komunikasi antarpribadi pada umumnya dipahami lebih bersifat pribadi (private) dan berlangsung 
secara tatap muka (face to face). Sebagian komunikasi antarpribadi memang memiliki tujuan, misalnya apabila untuk meminta saran atau pendapat kepada orang lain. Akan tetapi, komunikasi antarpribadi dapat juga ralatif tanpa tujuan atau maksud tertentu yang jelas misalnya ketika seseorang sedang bertemu dengan kawannya dan mereka lalu saling bercakap-cakap dan bercanda.

Dalam membina komunikasi antar orang tua dan anak harus ditanamkan sejak dini kepada anak. Agar mereka terbiasa bisa berkomunikasi dengan orang tuanya tanpa merasa malu dan terbebani dalam menceritakan semua yang terjadi pada diri anak tersebut. Hal ini juga akan memudahkan bagi para orang tua dalam mendidik dan mengawasi anaknya dalam hal pergaulan bebas yang sudah merajela dimana-mana. Dengan adanya komunikasi yang baik antar orang tua dan anak, akan menciptakan keluarga yang harmonis. Bisa menjadikannya sebagai contoh kepada anak, agar kelak anaknya membangun rumah tangga sendiri bisa menanamkan nilai-nilai keluarga yang telah dilihatnya dari orang tuanya.

Kita tahu, bahwa anak-anak sering kali menghadapi berbagai macam persoalan, kesulitan dan kekuatiran. Akan tetapi umumnya masih relatif kecil, tidak seperti yang kita hadapi. Dan kita memang memperhatikan mereka, terutama bila mereka kesusahan. Namun sebenarnya kita tidak sungguh-sungguh merasakan kesulitan mereka sebagaimana mereka rasakan kita mengira, bahwa kita sudah mengetahui jalan keluarnya.

Adalah sangat bijaksana jika orang tua menyediakan cukup waktu untuk percakapan yang sifatnya pribadi. Pada kesempatan seperti ini orang tua akan mendengar atau menemukan banyak hal di luar masalah rutin. Mungkin pula ada sesuatu yang serius. Dan sebagai orang tua dengan sendirinya kita pasti akan menjadi lega setelah anak-anak membuka isi hati, di samping kita harus cukup waspada dan berhati-hati untuk bisa memisahkan perasaan anak-anak dengan penangkapan orang tua. Bagaimanapun ada hal-hal yang bukan kompetensi mereka, sehingga perlu kita menempatkan segala sesuatunya dalam proporsi yang wajar.

Meluangkan waktu bersama merupakan syarat utama untuk menciptakan komunikasi antar orang tua dan anak. Sebab dengan adanya waktu bersama, barulah keintiman dan keakraban dapat diciptakan diantara anggota keluarga. Bagaimanapun juga tak seorang pun dapat menjalin komunikasi dengan anak bila mereka tak pernah bertemu ataupun bercakap-cakap bersama. 
Dengan meluangkan waktu dengan anak, para orang tua akan mengetahui bagaimana sebenarnya kepribadian anaknya. Begitu juga dengan anak, ia akan merasa sangat senang karena dapat perhatian dari orang tua nya. Hal ini akan memudahkan bagi sang anak untuk membicarakan semua yang terjadi terhadap dirinya, begitu juga dalam memilih calon pasangan hidupnya kelak. Ia tidak akan sungkan dan malu untuk membicarakannya dengan orang tuanya apabila keakraban sudah terjadi diantara orang tua dan anak.

Menurut Thomas Gordon, salah satu efektif dan konstruktif dalam mengahadapi ungkapan perasaan atau ungkapan persoalan anak-anak adalah "membuka pintu" atau "mengundang" untuk berbicara lebih banyak. Ini adalah tanggapan-tanggapan yang tidak berhubungan dengan pendapat, gagasan atau perasaan si pendengar, namun yang mengundang anak untuk membagi pendapat, gagasan atau perasaan-perasaannya. Hal ini membuka pintu bagi anak, mengajaknya untuk berbicara. (Sobur: 1985)

Membuka pintu atau menyilakan berbicara dapat memudahkan komunikasi. Hal ini mendorong anak untuk mulai atau meneruskan bicara. Cara ini juga membuat masalah tetap pada tempatnya, yaitu masalah anak. Disamping itu cara ini tidak mengakibatkan pengambilalihan masalah, sebagaimana halnya bila orang tua mengajukan pertanyaan-pertanyaan, memberi nasihat, mengajari, member khotbah dan sebagainya. Cara buka pintu ini menjauhkan perasaan-perasaan dan pendapat-pendapat orang tua dari proses komunikasi.

Dalam membina komunikasi antara orang tua dan anak juga terkadang para orang tua sering menghadapi masalah. Seperti yang dijelaskan Zakiah Drajat dalam bukunya ilmu jiwa agama sebagai berikut: "Seringkali terjadi pertentangan pendapat antara orang tua dan anak-anaknya yang telah remaja atau dewasa. Kadang-kadang hubungan yang kurang baik itu timbul, karena remaja mengikuti arus dan mode: seperti rambut gondrong pakaian kurang sopan, lagak lagu dan terhadap orang tua kurang hormat. Banyak dijumpai ketidakserasian hubungan antara remaja dan orang tuanya; yang menderita bukan remaja saja, tapi orang tua kadang-kadang lebih menderita lagi. Ada remaja yang patah semangat, mogok belajar, menjadi nakal, melawan kepada orang tua, merusak barang-barang dirumah, lari dari rumah, benc kepada orang tua, bahkan kadang-kadang sampai kepada niat akan membunuh orang tuanya karena sangat paniknya." ( Zakiat Drajat: 2005) Selain itu masalah yang dihadapi orang tua dalam menghadapi anak-anak nya adalah: 
a) Merasa Kurang disayangi. Orang tua sering kali menyangka, bahwa mereka cukup sayang kepada anaknya. Akan tetapi sekali anak-anak yang menderita, karena merasa tidak disayangi. Pada umumnya orang tua, menyayangi anak dengan caranya masing-masing, ada yang membelikan segala macam permainan berharga, mencukupkan makanan dan pakaian serta mengabulkan segala permintaannya; orang tua lainnya merasa cukup sayang, apabila ia mengkhususkan seorang pembantu untuk anaknya. Sebenarnya yang sangat dibutuhkan anak, bukanlah benda-benda atau hal-hal lahir itu, tapi jauh lebih penting dari itu adalah kepuasan bathin, merasa dapat tempat yang wajar dalam hati kedua ibu-bapakya. Mungkin saja kebutuhan materil kurang terpenuhi, karena orang tuanya kurang mampu, namunmia cukup merasakan kesayangan dari kedua orang tua nya itu. (Hasbi: 2004)

b) Perlakuan keras terhadap anak. Kadang-kadang orang tua menyangka bahwa perlakuan keras perlu dalam pendidikan anak. Kalau tidak, takut jangan-jangan si anak menjadi orang yang idak baik atau tidak tahu diri nantinya. Dan banyak pula orang tua, yang cenderung kepada memperlakukan anaknya seperti dia diperlakukan oleh orang tua nya dulu. Sehingga dalam mendidik anaknya, selalu diingatnya bagaimana orang tuanya mendidiknya dulu, apalagi kalau ia merasa dirinya berhasil dalam hidup.

c) Perubahan perlakuan terhadap anak. Sudah menjadi kebiasaan pula pada ibu-bapak yang baru mempunyai anak pertama, terlalu memperhatikan, sangat saying, sibuk dan cemas terhadap anak. Memang anak sulung seringkali menjadi percobaan bagi orang tua, karena belum pernah mempunyai anak sebelum itu. keadaan akan lebih gawat lagi, apabila anak sulung itu lama dapat adik. Semakin lama dia mendapat adik, akan semakin panjang masanya dia mendapat perhatian dan kesayangan yang berlebihan dari orang tuanya, sehingga banyaklah fasilitas dan keistimewaan-keistimewaan yang menggembirakan dirasakannya.

\subsection{Memilih Pasangan Hidup yang Ideal}

Manusia diciptkan Allah SWT berpasang-pasangan, ada pria dan wanita, masing-masing pihak saling membutuhkan dan saling tertarik satu sama lain. Hal ini dijelaskan Allah SWT dalam firman-Nya: “ dan di antara tanda-tanda kekuasaan-Nya ialah Dia menciptakan untukmu isteriisteri dari jenismu sendiri, supaya kamu cenderung dan merasa tenteram kepadanya, dan dijadikan- 
Nya diantaramu rasa kasih dan sayang. Sesungguhnya pada yang demikian itu benar-benar terdapat tanda-tanda bagi kaum yang berfikir ". (QS. Ar-Ruum: 21).

Allah juga menjelaskan bahwa istri atau pasangan pria itu diciptakan dari unsur pria itu sendiri agar mereka bisa mneruskan tugas Allah sebagai khalifah-Nya di bumi, antara lain dengan menikah, mengembangkan anak keturunan yang banyak. Hal ini ditegaskan dengan baik oleh Allah SWT dalam firman-Nya. Artinya: Hai sekalian manusia, bertakwalah kepada Tuhan-mu yang telah menciptakan kamu dari seorang diri, dan dari padanya Allah menciptakan isterinya; dan dari pada keduanya Allah memperkembang biakkan laki-laki dan perempuan yang banyak. dan bertakwalah kepada Allah yang dengan (mempergunakan) nama-Nya kamu saling meminta satu sama lain, dan (peliharalah) hubungan silaturrahim. Sesungguhnya Allah selalu menjaga dan mengawasi kamu. (QS. Al-Nisa: 1)

Dalam memilih calon pasangan hidup yang ideal banyak kategori-kategori yang di inginkan seseorang. Tidak hanya berpenampilan menarik dari luarnya saja, tetapi penampilan dari dalam juga sangat perlu. Begitu juga dalam memilih calon pasangan hidup yang ideal harus inner beauty (cantik/tampan luar dalam). Kecantikan maupun ketampanan seseorang itu relatif tergantung orang yang memandang dan menilainya. Ada orang yang cantik/ tampan dari luarnya saja tetapi tingkah laku nya tidak mencerminkan yang baik. Dan ada juga yang dari luar nya biasa-biasa saja dan standart tetapi dalam nya (perbuatannya) sangat baik.

Karena pada umumnya Allah SWT menciptakan semua yang ada di muka bumi ini berpasanganpasangan. Ada kaya dan juga miskin, ada pintar dan juga bodoh, ada juga yang cantik dan jelek dan sebagainya. Begitu juga dengan manusia diciptakan dengan berbagai kelebihan dan kekurangan. Karena tidak ada manusia yang sempurna di dunia ini. Semua mempunyai kelebihan dan kekurangan. Setiap wanita ingin mendapatkan pasangan calon suami ideal, yaitu yang ganteng, memiliki harta yang relatif cukup, atau memiliki pekerjaan yang baik dan halal, berasal dari keluarga/keturunan yang baik, cerdas (cukup berpendidikan), sehat (tidak sakit-sakitan), berakhlak mulia, dan taat dalam beribadah.

Bila mengalami kesulitan untuk memilih pendamping hidup yang ideal seperti di atas, maka pilihlah yang perangainya baik dan taat dalam beribadah kepada Allah SWT. Walupun dari 
keluarga miskin secara aterial wajah biasa-biasa saja. Hindari memilih pasangan hidup yang berbeda agama. Kecuali ada komitmen kuat darinya untuk memasuki agama Islam dan berperangai baik.

Untuk mengetahui lebih dalam tentang sifat dan perangai calon suami bisa memalui investigasi terhadap teman-teaman atau tetangganya serta dengan mengetahui keadaan keluarganya. Adapun kriteria tersebut didasarkan sesuai dengan hadist Rasul yang bisa juga dikiaskan untuk pria yaitu;

"wanita itu lazimnya dinikahi karena empat perkara; karena hartanya, karena keturunannya, karena kecantikannya dank arena agamanya, maka pilihlah wanita yang mempunyai agama (jika tidak) maka binasalah engkau" (HR. Bukhari Muslim).

Bila tidak bisa memenuhi kriteria sebagaimana prioritas yang disebutkan hadist diatas, Nabi saw menganjurkan agar memilih yang terakhir yaitu baik agamanya. Seorang suami juga senantiasa mendambakan istri yang shalehah, taat dalam menjalankan ibadah mahdhah seperti puasa, shalat, dan zakat. Rajin menjalankan syariat (hukum) sesuai aturan agama dan berbudi pekerti yang luhur (akhlakul mahmudah). Itulah gambaran sosok wanita ideal dalam pandangan Islam. Allah melalui Nabi Muhammad SAW, menggambarkan wanita shalehah itu sebagai perhiasan terindah bagi suaminya. Bila berada di dekatnya senantiasa menyenangkan, sehingga mampu memberikan rasa kebahagiaan bagi suami dan anak-anaknya.

Secara umum, sosok wanita ideal adalah jelmaan dari wanita shalehah itu. wanita dambaan kaum pria (suami) adalah wanita (istri) yang berakhlak mulia (akhlakul karimah). Potret wanita ideal itu akan digambarkan secara rinci dalan penjelasan berikut:

\section{a. Penyabar}

Sikap penyabar atau tabah dalam menghadapi segala bentuk penderitaan adalah anjuran agama dan pencerminan dari prilaku akhlak yang baik. Ada dua alasan yang membuat wanita (istri) secara kodrati harus bersikap sabar. Secara internal wanita memilki sifat yang lemah lembut dan kekuatn fisik yang lebih lemah dibandingkan kaum pria (suami).

\section{b. Memiliki Rasa Malu}


Malu atau al-Haya' adalah satu sifat terpuji, yaitu malu terhadap diri sendiri, malu terhadap orang lain (suami), juga malu terhadap Allah SWT harus lebih utama. Memiliki rasa malu itulh seorang istri tidak akan melanggar aturan agama, aturan suami, dan hat nuraninya. Orang yang memiliki rasa malu, pertanda ia masih memilki iman, sebagaimana di sabdakan Rasullallah bahwa, malu itu adalah sebagian dari iman.

\section{c. Sopan dan Lembut Saat Bicara}

Secara kodrati, wanita adalah makhluk yang lembut, sehingga sudah seharusnya ia bersikap sopan dan bertutur kata yang lembut kepada suami dan anak-anaknya. Perkataannya tidak saja bisa dimengerti namun juga sangat menyenangkan dan menyejukkan saat di dengar oleh telinga suaminya. Kata-kata yang lembut dan mesra haruslah di pertahankan oleh setiap istri atau wanita terhadap kekasihnya. Mendengar tutur kata yang sopan, manis dan mesra dari seorang istri, membuat semua kecapean bekerja yang dialami suaminya, seolah hilang dengan sendirinya.

\section{d. Memiliki Akhlak yang Baik}

Setiap istri hendaknya menghias diri dengan akhlak yang baik. Karena dengan akhlak yang baiklah, kehidupan rumah tangga akan mendapatkan ketenangan, ketentraman, dan kebahagiaan, baik lahir maupun bathin.

Demikianlah sosok wanita ideal. Sebuah sosok yang selalu menjadi dambaan setiap pria (suami), karena itulah, setiap wanita, hendaknya berusaha untuk memperbaiki diri, seraya berjuang keras menjadi wanita ideal, yaitu wanita yang shalehah, wanita yang selalu tampak cantik di lahir, juga selalu tampak cantik di bathin.

Begitu pula bagi seorang wanita dalam mencari pasangan hidupnya kelak, harus juga memiliki akhlakul karimah yang baik, sebagaimana yang telah dijelaskan di atas sama halnya dengan mencari pasangan hidup untuk seorang wanita.

\subsection{Hambatan-hambatan Komunikasi Antara Orang tua dan anak}


Dalam berkomunikasi tidak selamanya bisa berjalan dengan baik dan lancar. Ada hambatanhambatan yang di hadapai seorang komunikator dalam menyampaikan pesannya kepada komunikan. Begitu juga hambatan komunikasi antar orang tua dan anaknya. Hambatan-hambatan dalam komunikasi tersebut dapat dibedakan sebagai berikut:

1) Gangguan teknis. Gangguan terjadi jika salah satu alat yang digunakan dalam berkomunikasi mengalami gangguan, sehingga informasi yang ditransmisi melalui saluran mengalami kerusakan (channel noise). Misalnya gangguan pada stasiun radio atau TV, gangguan jaringan telefon, rusaknnya pesawat radio sehingga terjadi suara bising dan semacamnya. Begitu pula gangguan komunikasi antara orang tua dan anak yang jaraknya berjauhan. Biasanya komunikasi orang tua dan anak yang berjauhan melalui jaringan telefon. Dengan rusaknya jaringan telefon tersebut bisa menghambat komunikasi antara orang tua dan anaknya. Apabila hambatan gangguan teknik ini terjadi dengan anak dan orang tua, jika memang memungkinkan sebaiknya antara anak dan orang tua dapat bertemu secara langsung dan membicarakan calon pasangan hidup yang diinginkan oleh sang anak.

2) Gangguan semantik dan Psikolgis. Gangguan semantik ialah gangguan komunikasi yang disebabkan karena kesalahan pada bahasa yang digunakan. Gangguan semantik sering terjadi karena:

a. Kata-kata yang digunakan terlalu banyak memakai jargon bahasa asing sehingga sulit dimengarti oleh khalayak tertentu.

b. Bahasa yang digunakan pembicara berbeda dengan bahasa yang digunakan oleh penerima.

c. Struktur bahasa yang digunakan tidak sebagaimana mestinya, sehingga membingungkan penerima.

d. Latar belakang budaya yang menyebabkan salah persepsi terhadap simbol-simbol bahasa yang digunakan.

Dalam komunikasi antara orang tua dan anak gangguan semantik ini jarang terjadi karena pada umumnya anak dan orang tuanya mempergunakan bahasa yang sama. Kecuali anak dan orang tua nya tinggal di tempat yang berbeda suku atau budaya bisa menyebabkan miss communication di antara keduanya. 
3) Rintangan fisik. Rintangan fisik ialah rintangan yang disebabkan karena konsisi geografis misalnya jarak yang jauh sehingga sulit dicapai, tidak adanya sarana kantor pos, kantor telefon, jalur transfortasi dan semacamnya. Dalam komunikasi antarmanusia, rintangan fisik bisa juga diartikan karena adanya gangguan organik, yakni tidak berfungsinya salah satu pancaindra pada penerima. Rintangan komunikasi antara anak dan orang tua dalam rintangan fisik ini juga jarang terjadi.

4) Rintangan status. Rintangan status ialah rintangan yang disebabkan karena jarak sosial diantara peserta komunikasi, misalnya perbedaan status antara senior dan junior atau atasan dan bawahan. Perbedaan seperti ini biasanya menuntut perilaku komunikasi yang selalu memperhitungkan kondisi dan etika yang sudah membudaya dalam masyarakat, yakni bawahan cenderung hormat pada atasannya, atau rakyat pada raja yang dipimpinnya.

Di antara orang tua dan anak juga terdapat status yang berbeda, ada juga anak merasa sungkan dan malu untuk menceritakan semua masalahnya kepada orang tua nya. Karena menganggap orang tuanya orang yang paling dihormatinya. Apalagi untuk menceritakan calon pasangan hidupnya, kadang anak merasa malu dan segan kepada orang tuanya.

5) Rintangan Kerangka berpikir. Rintangan kerangka berpikir ialah rintangan yang disebabkan adanya perbedaan persepsi antara komunikator dan khalayak terhadap pesan yang digunakan dalam berkomunikasi. Ini disebabkan karena latar belakang pengalaman dan pendidikan yang berbeda.

Ini sering terjadi di antara orang tua dan yang pendidikan nya berbeda. Jalan pikiran diantara kedua nya juga sangat berbeda. Hal ini akan menghambat komunikasi diantara keduanya. Dalam hal memilih calon pasangan hidup terkadang terjadi perbedaan diantara anak dan orang tua karena berbeda kerangka berpikir diantara keduanya.

6) Rintangan budaya. Rintangan budaya ialah rintangan yang terjadi disebabkan karena adanya perbedaan norma, kebiasaan dan nilai-nilai yang dianut oleh pihak-pihak yang terlibat dalam komunikasi. Di negara-negara sedang berkembang masyarakat cenderung menerima informasi dari sumber yang banyak memiliki kesamaan dengan dirinya, seperti bahasa, agama, dan kebiasaan-kebiasaan lainnya. 
Seandainya anak atau orang tua menghadapi masalah dan mengutarakannya, salah satu pihak biasanya merasa perlu untuk membantu pihak lain. Yang lebih sering terjadi adalah oang tua berusaha untuk ikut menangani masalah yang dihadapi anak. Sayangnya iktikad baik ini sering kali tidak mencapai hasil yang diinginkan. Anak tetap merasa bahwa masalahnya tidak terselesaikan, atau bahkan lebih dari itu anak merasa bahwa orang tua sebenarnya tidak mengerti apa yang dirasakannya, meremehkan perasaannya, bahkan tidak jarang keluhan anak disambut dengan sikap menyalahkan dari pihak orang tua. Bila ini terjadi berarti komunikasi antara kedua belah pihak telah mengalami hambatan. Dalam hal ini orang tua telah bersikap tidak efektif dalam menanggapi masalah yang dialami anak. Apabila hal ini terjadi antara anak dan orang tua dalam memilih calon pasangan hidup sebaiknya dibicarakan baik-baik diantara keduanya. Bagaimana keinginan anak dan orang tua untuk calon pasangan hidupnya kelak.

\subsection{Solusi Dalam Berkomunikasi Antara Orang tua dan Anak}

Setiap ada permasalah yang ditimbulkan pasti ada solusi dalam menyelesaikan masalah tersebut. Begitu juga komunikasi antara orang tua dan anak. Apabila terjadi masalah diantara keduanya, harus mencari jalan keluarnya. Masalah-masalah yang sering dihadapi orang tua dalam berkomunikasi dengan anaknya, diantaranya adalah:

a. Punya kesibukan masing-masing. Kesibukan yang sering terjadi kerap dianggap sebagai pemicu renggangnya komunikasi dalam keluarga. Ada anggota keluarga yang sibuk bekerja dari pagi sampai malam, sehingga tidak ada waktu untuk berkomunikasi dengan anggota keluarga. Atau sekolah, dan kuliah bahkan tinggal berjauhan di kota lain. Hal ini biasanya semakin parah jika anak-anak dalam keluarga semakin beranjak besar dan sudah mandiri. Waktu untuk berkumpul bersama jadi makin berkurang karena semua anggota keluarga sibuk dengan urusan masing-masing. Untuk menyelesaikan permasalah ini, sebaiknya anggota keluarga meluangkan waktu beberapa jam untuk bisa berkomunikasi dan membicarakan halhal yang sangat penting, seperti kebutuhan anak, setidaknya menanyakan kabar atau kondisi keduanya. Bila diantara keluarga tersebut sudah berjauhan sebaiknya sering melakukan komunikasi melalui media handphone. Dalam memilih pasangan hidup pun anak harus berkomunikasi dengan orang tuanya. Walaupun orang tuanya sibuk dengan urusan masingmasing. Kadang bagi orang tua yang sering punya kesibukan jarang peduli dengan keinginan 
anaknya, dia memberi kebebasan kepada anak, apalagi untuk menentukan pasangan hidup anaknya. Bagi anak yang mempunyai orang tua yang sibuk dengan urusannya sendiri, sebaiknya langsung menceritakan calon pasangan hidup yang diinginkannya, kebanyakan orang tua seperti ini langsung memberikan keputusan kepada sang anak dalam memilih calon pasangan hidup anaknya.

b. Merasa segan dengan orang tua. Tidak jarang bahwa anak sekarang lebih sering cerita kepada orang lain dibandingkan dengan keluarganya, terutama kedua orang tua nya. Anak merasa kalau bercerita kepada orang tuanya merasa segan atau terbebani. Apalagi kalau anak yang mempunyai orang tua yang over protektif ( selalu melindungi anak dan merasa khawatir terjadi sesuatu kepada anaknya dan selalu ingin tahu keadaan sang anak). Hal ini membuat anak merasa risih, dan lebih cenderung berdiam diri daripada bercerita kepada orang tuanya. Untuk menyelesaikan permasalah tersebut, sebaiknya orang tua mendekatkan diri terhadap anak, melakukan komunikasi dengan face to face (tatap muka secara langsung). Apalagi kalau menyangkut pasangan hidup anaknya. Komunikasi dalam keluarga menjadi lebih baik apabila saat masing-masing anggota keluarga dapat mengemukakan pendapatnya ketidaksukaan dan keinginannya kepada anggota keluarga yang lain kemudian mencari solusi bersama. Hal seperti akan memudahkan anak dalam berkomunikasi dengan orang tua apabila diantara keduanya sudah saling terbuka satu sama lainnya.

\section{KESIMPULAN}

Bahwa dalam berkomunikasi antara anak dan orang tua harus saling terbuka, tidak ada yang ditutup-tutupi. Apalagi anak yang sudah beranjak dewasa pasti pola pikirnya sudah berbeda dengan anak remaja. Khususnya dalam memilih calon pasangan hidupnya kelak. Sang anak harus berkomunikasi dengan orang tua sebelum memperkenalkan calon pasangan hidupnya, sampai ketahap selanjutnya. Bila terjadi hambatan-hambatan dalam berkomunikasi antara anak dan orang tua, sebaiknya dibicarakan secara langsung dan bertatatap muka (face to face), agar apa yang diinginkan anak dan orang tua bias tercapai sesuai keinginan. Apalagi bagi seorang wanita biasanya lebih dekat dengan ibunya. Agar anak tidak salah dalam memilih pasangan hidup yang tidak hanya disukainya sendiri tetapi juga disukai dan direstui orang tuanya. Komunikasi yang 
baik antara anak dan orang tua akan memudahkan keduanya untuk saling terbuka dan membicarakan hal-hal yang diinginkan satu sama lainnya.

\section{DAFTAR REFERENSI}

Alex Sobur. Komunikasi Orang Tua dan Anak, Bandung, PT Angkasa: 1985

Cangara, Hafied. Pengantar Ilmu Komunikasi. Jakarta: PT Raja Grafindo Persada, 2009

Drajat, Zakiah Ilmu Jiwa Agama. Jakarta, PT Bulan Bintang: 2005

Effendy, Onong Unhjana. Ilmu Komunikasi Teori dan Praktek. Bandung: PT Remaja Rosdakarya, 2005

Faisal, Sanapiah. Format-format Penelitian Sosial, Jakarta: PT Raja Grafindo Persada, 2008

Indra, Hasbi, dkk. Potret Wanita Shalehah. Jakarta: Penamadani, 2004

Kholil, Syukur Teori Komunikasi Massa. Bandung, Cita Pustaka: 2011 